\title{
Sexual Promiscuity and Health Issues among Female Undergraduate Students in Adekunle Ajasin University: Counselling Implications
}

\author{
Dr (Mrs.) Beatrice O. Ajidahun \\ Department of Guidance and Counselling, \\ Faculty of Education,Adekunle Ajasin University, \\ Akungba-Akoko, Nigeria
}

Doi: $10.1515 / m j s s-2017-0048$

\section{Abstract}

This study examined the promiscuous behaviour of female undergraduate students and the various health issues related to it. It also investigated the relationship between the University lifestyles and female students' promiscuous behaviour. The study adopted descriptive survey with a sample of one hundred and twenty (120) undergraduate female students selected using simple random sampling technique. A questionnaire titled "Sexual Promiscuity (SP) designed by the researcher was used to collect data for the study. Two hypotheses were formulated to guide the result of the study. The study revealed that there was a significant relationship between the female undergraduates' promiscuous behaviour and their University lifestyles $\left.X^{2}=178.092<0.05\right)$. Also, there was significant relationship between the promiscuous behaviour and sexually transmitted diseases $\left(X^{2}=70.69<0.05\right)$. It was therefore concluded that female undergraduate students of Adekunle Ajasin University were promiscuous because of their University lifestyles and that many were exposed to various sexually transmitted diseases that affect their health. Recommendations were based on the findings of the study that the University lifestyles of students should be modernized to discourage promiscuous behaviour among female undergraduate students. Besides, adequate health and counselling seminars should be organized on regular basis to intimate female students with the consequences of such promiscuous lifestyles.

Keywords: Promiscuity, Health Issues, Counselling, Female Undergraduates, Sexual Behaviour.

\section{Introduction}

In the past as observed by the researcher, sexual attitude was allowed for procreation in the confines of marriage. Premarital sex then was not allowed until one was properly married. This cultural practice though still in existence is not as firm as it used to be in the past. According to Adegoke (2003), technological advancement has made the world to become a global village which provides unlimited access to information about sex from other countries of the world to the youths. Most of the information received from the net are defective and as such have effect on the sexual behaviour of adolescents and youths. This risk sexual behaviour among adolescents and youths in the university has continued to lure them to engage in early sexual debut, unsafe sexual activity, multiple and casual sexual partners. The author claimed that several responses on the sexual behaviour indicated that the age of first sexual debut had continue to decline among both male and female students in Nigeria.

The University lifestyle in Adekunle Ajasin University is influenced by the university off campus policy. Almost $80 \%$ of the students' populace are staying outside the university campus. It seems to the researcher that this policy might have lured many undergraduate girls to be having multiple sex 
partners. There is no regulation against such activities and behaviours in the university.

According to Abdullahi \& Abdullahi (2013), the university environment allows free sexual activities, and this is against the moral values of the community although the university campus according to Romio(2017) is known to provide academic stimulant as well as variety of activities and opportunities. Unprotected sexual behaviour is also on the increase among university students. This is made possible because university students enjoy freedom from their parents and the staff may not be bothered about how they live their lives.

Cohabitation is another trend that promotes sexual activities among university students. According to Seltzer (2000), cohabitation is a lifestyle in which an unmarried man and an unmarried woman are involved in a sexual relationship and live together in an informal union. Many students are involved in cohabitation because of so many reasons best known to them. Miriam (1999) observed that lack of parental control over the dating behaviour of undergraduates might have reinforced a normative climate toward early sex.

Kheswa and Mahlalela (2013) referred to sexual promiscuity as sexual activities with different partners and that the behaviour can have undesirable effects such as HIVIAIDS and other sexual transmitted infections. Also Mark et al (2011) agree that promiscuity can be understood as the willingness to engage in sexual activities with several partners, having casual sex and getting involved in sexual activities early than later. To Garcia et al (2010), sexual promiscuity can be defined as the engagement in uncommitted sexual activities with non-monogamous partners and with multiple partners.

The University environment encourages undergraduate females' desire for sex. This is because the University lifestyle gives them the opportunity to be freer from parental monitoring. Ikpe (2003) observed that the desire for material things like expensive jewelries and flashy phones lured female undergraduates into such life. The author also observed that many girls hide under the search for academic advantage by sleeping with students and even their lecturers. Peer influence and provocative dressing were also identified as reasons for promiscuous attitude among female undergraduates. Fuligni et al (2000) confirm that the pressure to conform to groups' behaviour is strong among undergraduate students. They are interested in what is in vogue so that they can feel belonged and be accepted by their peers.

According to Ajidahun (2015), a lot of home videos shown on the Nigerian television screen, the spoken words, and the actions that are dramatized also show a lot of sexual acts. Female undergraduates are exposed to many of these home videos on their laptops, cellphones and cinema houses. Bradley and Corwyn (2002) confirmed that distress among poor parents due to their economic pressure may lead to their female children's promiscuous attitude. Many female undergraduates in Adekunle Ajasin University are likely to be from poor homes.

Many of them could not afford to pay their school fees, buy adequate food stuff and fulfil other important desires that require money which may be difficult and this can lure them to have several sex partners to meet all the needs. So, sex is used to overcome poverty. This is confirmed by Kheswa \&Mahlalela (2014) that at a stage, 92\% of school girls indicated that they were enslaved for sex in exchange for gifts and money for economic survival. Orubuloye in Abdullahi \& Abdullahi (2013) observed that some students engage in promiscuous behaviour without even at first considering the overall effect. They see sex as means of enjoying pleasure and for fun.

Kheswa \&Mahlalela (2014) observed that promiscuous attitude of female undergraduates can have undesirable effects on their health such as HIVIAIDS and other sexual transmitted infections. Apart from this, some may end up being pregnant and be forced to leave the school prematurely. Some have committed abortions severally and some have died in the process. Comer (2013) said many have suffered psychological problems which have affected their health and wellbeing. Diseases like gonorrhea, syphilis, herpes, virginalis are high among girls who are sexually promiscuous.

Varga (2000) reported that many African youths and adolescents are at risk continually because of their riskily sexual practice. Such sexual practices include early initiation of intercourse, low use of contraceptives, multiple sex partners and poor sexual negotiation skills. Okafor and Obi (2005) opined that in a study carried out that the prevalence of sexual activity was $76.8 \%$ among University students. That $85.4 \%$ of the females while 62.3 of the males are having more than one 
sexual partners. This reveals that female undergraduates are involved in promiscuous attitude as $67.5 \%$ of females had their first sexual intercourse as adolescents as against $42.2 \%$ of their male counterparts.

The literatures reviewed show that there is high sexual promiscuous attitude among female undergraduates and its related effects on their health. This has resulted to unwanted pregnancy, illegitimate children, feeling of guilt and shame, emotional instability, dropping out of the university and becoming unhealthy due to sexual transmitted diseases. Sometimes many who have attempted to commit abortions have died in the process. The main cause of these regrettable situations is simply because of promiscuous attitude of female undergraduate students. Many are also suffering from psychological problems like sexual disorder and social maladjustment problems that require adequate counselling.

\section{Purpose of the Study}

The purpose of the study is to determine:

1. how University lifestyle contributes to female undergraduates' sexual promiscuity.

2. the relationship between female undergraduates' sexual promiscuity and their health issues.

3. the importance of counselling in resolving the promiscuous behaviour of female undergraduate students.

\section{Hypotheses}

Two hypotheses were formulated to guide the study

1. There is no significant relationship between the University lifestyle and female undergraduates' sexual promiscuity.

2. There is no significant relationship between the female undergraduates' sexual promiscuity and their related health problems.

\section{Methodology}

The research design used for this study is descriptive survey type. This made the gathering of information possible among the female students of Adekunle Ajasin University, Akungba Akoko.

The population of the study consists of all regular female students in Adekunle Ajasin University Akungba Akoko Nigeria who are in the age range of 17-23. A total number of 120 female undergraduates were randomly selected using simple random sampling technique. The samples were assured of the confidentiality of their responses.

The research instrument used for the study was a self-constructed questionnaire titled "Sexual Promiscuity Questionnaire (SPQ). The questionnaire consists of 15 items of two sections which are section $A$ and $B$. Section $A$ contains the bio data information of the female undergraduate students like age, sex, off campus and hostel facility. Section B consists of fifteen items which answer the two hypotheses formulated.

\section{Data Analysis}

The data were analyzed using chi-square statistical method. All hypotheses were tested at 0.05 level of significance.

\section{Findings}

Hypothesis one: There is no significant relationship between the University lifestyle and female undergraduates' sexual promiscuity. 
Table 1: A 2 x 6 Contingency Table Showing University Lifestyle and Female Sexual Promiscuity.

\begin{tabular}{|l|c|c|c|c|c|c|c|}
\hline & Sex partner & Pleasure & Freedom & Needs & Off Campus & Academic Advantage & Total \\
\hline Female Promiscuity & $86(82.5)$ & $74(82.5)$ & $30(82.5)$ & $110(82.5)$ & $114(82.5)$ & $81(82.5)$ & 495 \\
\hline University Lifestyle & $34(37.5)$ & $46(37.5)$ & $90(37.5)$ & $10(37.5)$ & $06(37.5)$ & $39(37.5)$ & 225 \\
\hline Total & 120 & 120 & 120 & 120 & 120 & 120 & 720 \\
\hline
\end{tabular}

$x^{2} \mathrm{c}=178.092, \mathrm{x}^{2} \mathrm{t}=11.07, \mathrm{df}=5$

Since $x^{2}$ calculated at 0.05 level of significance and $5 \mathrm{df}$ is greater than $\mathrm{x}^{2}$ critical value, the null hypothesis is rejected. Therefore, it can be concluded that female sexual promiscuity depends on the University lifestyle.

Hypothesis Two: There is no significant relationship between the female undergraduates' sexual promiscuity and their related health problems.

Table 2: A 2x7 Contingency table showing Female Sexual Promiscuity and Related Health Problems

\begin{tabular}{|l|c|c|c|c|c|c|c|c|}
\hline & $\begin{array}{c}\text { Disease } \\
\text { vector }\end{array}$ & STD Real & $\begin{array}{c}\text { STD } \\
\text { Irreversible }\end{array}$ & $\begin{array}{c}\text { Psychological } \\
\text { Effect }\end{array}$ & $\begin{array}{c}\text { High } \\
\text { Risk }\end{array}$ & $\begin{array}{c}\text { Weak to } \\
\text { Read }\end{array}$ & Bareness & Total \\
\hline $\begin{array}{l}\text { Female Sexual } \\
\text { Promiscuity }\end{array}$ & $71(100.43)$ & $104(100.43)$ & $\begin{array}{c}102 \\
(100.43)\end{array}$ & $98(100.43)$ & $\begin{array}{c}114 \\
(100.43)\end{array}$ & $\begin{array}{c}107 \\
(100.43)\end{array}$ & $\begin{array}{c}107 \\
(100.43)\end{array}$ & 703 \\
\hline $\begin{array}{l}\text { Related Health } \\
\text { Problem }\end{array}$ & $49(19.57)$ & $16(19.57)$ & $18(19.57)$ & $22(19.57)$ & $6(19.57)$ & $13(19.57)$ & $\begin{array}{c}13 \\
(19.57)\end{array}$ & 137 \\
\hline Total & 120 & 120 & 120 & 120 & 120 & 120 & 120 & 840 \\
\hline
\end{tabular}

$\mathrm{X}^{2} \mathrm{C}=70.69, \mathrm{X}^{2} \mathrm{t}=12.59, \mathrm{df}=6$

Since $x^{2}$ calculated at 0.05 level of significance and $6 \mathrm{df}$ is greater than $x^{2}$ critical value, the null hypothesis is rejected. Therefore, it can be concluded that female sexual promiscuity can lead to health problems.

\section{Discussion}

The result in table 1 shows that there is significant relationship between female sexual promiscuity and University lifestyle. The promiscuous sexual attitude of female students in the university is enhanced by the lifestyle of University students. The finding agrees with Abdullahi and Abdullahi (2013) that university environment allows freer sexual activities. Also it agrees with Miriam (1999) who observed that lack of parental control over university students have lured them to imbibe the university lifestyle. Since most of the students are far from home, they feel free to live anyhow. Besides, their parents are not always available to monitor their activities. Another common trend in the university lifestyle is cohabitation. The finding agrees with Seltzer (2000) that cohabitation is a lifestyle common among young people. In Adekunle Ajasin University, cohabitation is common and most female undergraduates live with the opposite sex under the guise of either receiving or providing financial assistance.

The result in table 2 shows that there is significant relationship between female sexual promiscuity and their related health problems. The sexual promiscuity among university female undergraduates can lead to health problems through sexually transmitted diseases. The findings agree with Kheswa \&Mahlalela (2014) that the promiscuous attitudes of female undergraduates have undesirable effects on their health such as HIVIAIDS and other sexual transmitted infections.

Also Comer (2013) said that sexual promiscuity can lead to psychological problems which affect the health and wellbeing of female students. The author further explained that diseases like gonorrhea, syphilis, herpes and virginalis are high among girls who are sexually promiscuous. Many female undergraduate students may be absent in school for several months in order to receive medical attention because they are not healthy enough to continue with the rigours of academic activities. 


\section{Conclusion}

It is obvious from the findings of the study that university lifestyle encourages promiscuous attitude among female undergraduates. Also, it is also clear from the study that sexual promiscuity may lead to health issues and therefore hinder their academic activities and even claim their lives. Female undergraduate students enjoy freedom from their parents, the desire to satisfy material needs and academic advantages have lured many into promiscuous lives.

There is the need to be concerned about this trend in the university because many promising girls had been affected academically socially and psychologically. The efforts of counsellors in the university system cannot be overemphasized. There is the need to employ the services of professional counsellors to address this problem among female undergraduates. Many are naïve and ignorant of their actions. The counsellor will be able to tell them when, how and who to engage in sexual relationship.

\section{Recommendation}

The following recommendations are made based on the finding of the study:

1. The university system should discourage promiscuous attitude by providing adequate information to parents about the whereabouts of their wards especially the female undergraduate students. This will curb the activities of girls who abscond from school to meet men in far places for reward of money.

2. Also, the university should have a policy to discourage cohabitation among students, off campus policy should be reviewed; more hostel facilities should be built to accommodate more females undergraduate into the hostels.

3. Regular seminars should be organized by the counsellors to intimate female and male undergraduates about the undesirable effects of promiscuous life on their health and wellbeing.

4. Qualified and professional counsellors should be recruited by the university to help handle the sexual problems of undergraduate students especially the female undergraduate students, because they are always at the receiving end of sexual activities. Promiscuous sexual behaviours make them to be vulnerable to sexually transmitted diseases.

\section{References}

Abdullahi, M and Abdullahi, U. (2013) "Factors Associated with Engaging in Pre-Marital sex

among the Students of University of Maiduguri." International Journal of Humanities and Social Science Invention. Volume 2.

Adegoke, A.A. (2003). Adolescents in Africa: Revealing the Problems of Teenagers in a Contemporary African Society. Ibadan: Hadassah Publishing.

Ajidahun, B.O. (2015) "Parental Moral Training and Adolescents' Sexual Values in Adekunle Ajasin University, Akungba Akoko." British Journal of Education, Society and Behaviour Science 10(4) pg 1-8.

Bradley, R.H. and Corwyn, R.F. (2002). "Socio-economic Status and Child's Development." Annual Review of Psychology 53(1) pg.

Comer R.J. (2013). Abnormal Psychology. Library of Congress. United States of America.

Fuligni, A.J. (1997). "The Academic Achievement of Adolescents from Immigrant Families: The Roles of Family Background, Attitudes and Behaviour." Child Development 68, 351-363.

Garcia, J.R., Mackilop, J., Aller, E.L., Merriwther A.M., Wilson, D.S., Lum, J.K. (2010). Associations Between Dopamine D 4 Receptor Gene Variation with Both Infidelity and Sexual Promiscuity plus one (5).

Ikpe, E.B. (2003) "Sexual Negotiation in Tertiary Institution in Nigeria." Journal of Interdisciplinary of National Association of Academic Vol 1.

Kheswa, J. and Mahlalda (2014). "Sexual Promiscuity Among African Adolescent Females in Sub-Saharan Countries." Mediterranean Journal of Social Sciences.

Marks, N.E., and Lambert, J.D. (1998). "Marital Status Continuity and Change among Young and Midlife Adults." Journal of Family Issues, Vol 19. 652-686.

Miriam, J.I. (1999) "Perception on Sexual Transmitted Diseases Among Adolescents in Benin City." International Family Planning Perspectives. Vol 15, No 4. 
Okafor, I.I and Obi, S.N. (2005). Sexual Risk Behaviour Among Undergraduate Students in Enugu, Nigeria. Journal of Obstetrics and Gynecology 25(6). 592-595.

Romio,E.F(2017) Acquintance Rape on College and University Campuses.Retrieved on 27/5/2017 from htt://www.splc.org/news flash.as?id=768

Seltzer, J.A. (2000). "Families Formed Outside of Marriage." Journal of Marriage and Family 62, 1247-1268.

Varga,C.A. (2000).Condom dilemma:Dynamics of Projected Sex in High risk groups in South African, Health Trasition Centre.The Australian National University Cambenra pg 39-62. 